\title{
Cezary Wodziński
}

\section{Na progu* \\ DOI 10.35757/CIV.2016.19.11}

Ktoś jest i skąd? Przepytajmy raz jeszcze samego Odyseusza, pamiętając o właściwej mu w stopniu najwyższym sztuce - techne - politropiczności.

Nieoczekiwany przybysz zwykle budzi ciekawość. Jak choćby Atena, która już w pieśni I ukazuje się Telemachowi pod postacią tafijskiego króla Mentesa. Syn Odyseusza pyta ja ukradkiem, by choć jedno słowo nie doszło do ucztujących zalotników:

A teraz się do cię zwracam,

byś ciekawości mojej też dogodził:

$Z$ jakiegoś ludu, miasta? Mów mi, gdzieś się rodził?

Jakeś się dostał... (I 188-190; LS, 12)

Eu eido... - co w innym przekładzie zostaje dokładnie przetłumaczone: „Ktoś jest i skąd?” (I 174; JP, 9).

Homerycka gościnność nie pozwalała stawiać takich pytań natychmiast (zob. Iliada, przypis 543). Ustalenie tożsamości przybysza: imię, ród, miejsce pochodzenia, cel podróży i tak dalej, następowało po pewnym czasie. Przeważnie po wstępnym ugoszczeniu przybysza i zaspokojeniu jego elementarnych potrzeb (odpoczynek, głód - „głód największym tyranem”, powiada Odyseusz [VII 229; LS, 105], pragnienie, czystość). Ciekawość - właściwe pragnienie - bywa hamowana i odraczana na czas zaspokojenia potrzeb.

Tak jest przy pierwszym spotkaniu Telemacha $z$ Atena (i ten rytuał będzie się $\mathrm{w}$ ich relacjach powtarzał $\mathrm{z}$ powodu polimorficzno-

* Fragment książki Cezarego Wodzińskiego, Odys gość. Esej o gościnności, Fundacja Terytoria Książki, Gdańsk 2015, s. 117-131. 
ści epifanii bogini). Pytanie o tożsamość boskiego gościa zadaje też wścibski Eurymachos, ale Telemach - „przeczuwając, że ten gość był bogiem" (I 443; LS, 19) - roztropnie uchyla się od odpowiedzi.

Pytanie „ktoś jest i skąd?” towarzyszy Telemachowi w jego podróżach. Każdy epizod Telemachii zawiera moment badania i przepytywania przybysza.

W Pylos - po ugoszczeniu - Nestor bada Telemacha i jego drużynę:

Teraz wolno mi spytać przybyłych tu gości

Kto sa...

Mówcie: co wy za jedni... (III 70; LS, 36)

kseinous, oi tines eisin (wypytać gości i zbadać; III 70; JW, 63).

U Menelaosa w Lakedemonie przepytywanie Telemacha zostaje od razu odroczone:

Cni goście... Potem będę pytał,

Gdy się już posilicie, coście to za jedni (IV 62; LS, 51).

Badanie przeprowadza pośrednio Helena, która podczas rozpoznawczej uczty pyta męża:

Czy wiemy, Menelaju, jaki ród tych gości,

Co przyszli w domu naszym szukać gościnności? (IV 135; LS, 53)

Rozpoznaniu Telemacha i jego boskiego rodowodu towarzysza okrzyki świadczące o boskiej epifanii:

O popoi, e mala de... (IV 169: „Przebogi” [LS, 54]; „Wielkie nieba” [JP, 50]; „Na bogów” [JW, 81]; „Przez bóg żywy!” [SM, 39])

Telemacha przepytuje też wieszczek Teoklimenos: „Ktoś jest” (XV 260; LS, 231).

Zakres pytania „Ktoś zacz?” nie ogranicza się tylko do znaczeń związanych $z$ szeroko pojętą „tożsamościa”" i swoistą dialektyką odroczenia pragnienia ciekawości. Może oznaczać radykalna 
wstrzemięźliwość i zawieszenie działania prawa tożsamości. Politropiczny Odyseusz dobrze zdaje sobie $z$ tego sprawę i nadaje temu momentowi range zasady.

Lżącemu go Melantiosowi, który gotów go przepędzić $z$ (jego własnego) domu, odpowiada:

W moim zamku, i często przychodniów wspierałem;

Co za jedni i skąd sa, nigdy nie pytałem (XIX 77; LS, 290).

Piękna Nausikaa chroni Odyseusza przed nieprzyjazna wścibskością dumnych Feaków:

... by... go nie złajał lub nie spytał z góry,

Co zacz (VII 20; LS, 99).

Ujawnienie tożsamości - zwłaszcza przedwczesne - może być zagrożeniem. Mogłoby również pokrzyżować misterne knowania...

Coś zacz? Ten sam schemat badawczy stosowany jest za każdym razem, gdy pojawia się Odyseusz.

W pałacu Alkinoosa odegrany zostaje pokazowy spektakl dialektyki zaspokojenia potrzeby i odroczonego pragnienia ciekawości. Dopiero po ugoszczeniu przybysza i obłaskawieniu „największego tyrana" głodu królowa Arete zadaje sakramentalne pytanie, które pozwala Odyseuszowi rozpoczać długą opowieść:

Gościu, pozwól, żeć jedno zapytanie zrobię:

Coś zacz, skąd się tu wziąłeś? (VII 250; LS, 106)

Wielosegmentowa, wieloznaczną, w najściślejszym sensie politropiczna odpowiedzia na to pytanie jest cała Odyseja. Ale pytanie to powtarza się w pieśniach Odysei monotonnie, z pewna stanowczą uporczywością.

Niepomny jakby pytań Arete, to samo badanie wszczyna podczas uczty po igrzyskach Alkinoos: 
...wykrętnym słowem nie wywódź mnie w pole...

Mów: jakim cię nazwiskiem zwie ojciec i matka...

Przecież nikt bez nazwiska po świecie nie chodzi!

...mów prawdę goła.... (VIII 550; LS, 126)

eip' onom'... (VIII 550: „swoje imię istotne” [SM, 98]; „Powiedz imię...

Nie masz bowiem człowieka bezimiennego": anonymos est' anthropon [552; JP, 119]).

Tymczasem - pomimo wielokrotnego ujawniania imienia - Odyseusz pozostaje „człowiekiem anonimowym”. Ukrywa się przebiegle w kryjówce swego anonimatu.

I ukrywa się w nim tym bardziej, im częściej i bardziej natarczywie pada pytanie... Zaciera - czego spektakularnym dowodem epizod z cyklopem - różnicę między Odys i Udeis. Do niepoznaki. Gra w Niktoś niestrudzenie.

Za każdym razem przeskakując zwinnie próg natrętnego pytania, które zadaja mu niemal wszyscy napotkani. Za każdym razem sprytnie się wymigując, wyślizgując niczym w przesmyku między Scylla i Charybdą. Przemykajac się...

Odyseusza badaja kolejno: Polifem (IX 263), Eol (X 15), Kirke, przerażona, że gościa nie imają się jej czary (pyta się go: „Ktoś jest? $Z$ jakiego ludu? Który kraj cię rodzi?” - tis, pothen eis andron... toi polis [X 325; LS, 154], i sama odgaduje: „niechybnie Odys zmyślny" [SM, 121]), pastuch Eumajos (XIV 188).

Wreszcie troje najbliższych mu osób. Jako pierwszy Telemach, pośrednio, rozpytujac Eumajosa: „...skąd gość ten u ciebie się zjawił?” (XVI 59). Potem Penelopa, która badanie przeprowadza rzeczowo i systematycznie (,... aby... Odpowiadał na różne pytania”):

Obcy człeku! Przed wszystkim spytam na poczatek:

Coś zacz i w jakiej ziemi twe gniazdo ojczyste?

Odyseusz wymyka się: „...w tym domu o rzeczy rozpytuj mnie inne!” (XIX 100-118; LS, 291). W końcu ojciec: „Przychodniu!.. Skądeś jest i gdzie twoi mieszkają rodzice" (XXIV 287-307; LS, 368). Dlaczego nie zadaja tego pytania zalotnicy? Nie ciekawi 
ich odpowiedź? Nie podejrzewaja podstępu? Nie, ich brak zainteresowania tożsamością przybysza, przybłędy wynika $z$ tego, iż $\mathrm{w}$ zainscenizowanej przez nich scenerii zakłóceniu uległy prawa gościnności, co sprawi, że w ogóle nie traktuja go jako Gościa.

Uporczywe powtarzanie pytania - w zmiennych konfiguracjach badawczych i kręgach ciekawości - świadczy, że pytanie pozostaje zasadniczo bez odpowiedzi. Pytanie jest stale... na poczatku, na końcu, pomiędzy. Żadna odpowiedź - a Odyseusz udziela ich wiele i na wiele sposobów: wykrętnie i wprost, skrycie i jawnie... - nie znosi mitologosowej mocy pytania.

Imię „Odyseusz” jest odpowiedzią na pytanie: „Ktoś jest?”. Ale w tym przewrotnie odysowym sensie, że mnoży znaki zapytania i sieje niepewność. Jest „odpowiedzią" w nieznośnym znaczeniu Znaku Zapytania.

Dygresja leksykalna. Niewiele słów pojawia się w Odysei równie często, jak rzeczownik ksenos, który u Homera występuje w jońskiej formie kseinos (ei oznacza tu wzdłużenie zastępcze, powstałe na skutek wypadnięcia archaicznej digamma $f$ ze słowa ksenfos; zob. RAP, 5; MAD, 118).

Przesądza o tym przede wszystkim jego wieloznaczność. Ksenos to:

1. gość (zwiąany przyjaźnia i gościnnością na prawach wzajemności);

2. udzielający gościny, gospodarz, pan domu (u Homera często w złożeniu kseinodokoi kai kseinos: gościnodawca i gość; zob. SM, 97);

3. cudzoziemiec, tułacz, zbieg, przybysz, obcy, obcokrajowiec (jak czytamy w komentarzu: „obcy, gość - po wymianie podarków gościnnych staje się przyjacielem, związanym węzłem gościnności. Stosunek ten jest dziedziczny: patroioi: po ojcach jeszcze, już z czasów ojca, przyjaciele gościnni, pobratymcy"; zob. RAP, 228);

4. najemnik, żołnierz najemny, sprzymierzeniec;

5. w Sparcie synonim: barbaros. 
Jako przymiotnik kseinos to: obcy, cudzoziemski; nieobeznany, nieznajacy; ale także: niezwykły, osobliwy (to ksenon: niezwykłość), odmienny.

Jako przysłówek to: obco, niezrozumiale.

Wieloznaczność rzeczownika oparta jest na dwóch napięciach semantycznych, rozgałęzionych niekiedy do postaci opozycyjnych znaczeń:

- gość (przyjaciel) - obcy (wróg);

- gość (korzystający z gościny) - gospodarz (udzielający gościny). Semantyczna dynamika ksenosa wynika przede wszystkim $z$ tranzytywności zapisanych $\mathrm{w}$ nim znaczeń, $z$ ich ruchliwej przechodniości, która nie pozwala przypisać słowu trwałych i stabilnych znaczeń. Przestrzeń ksenotyczna jest dynamiczna i transgresywna. Niczym sam „gość”, który gotów obrócić się niespodzianie w „gospodarza”, z „przyjaciela” przeinaczyć się we „wroga”. I na odwrót.

W orbicie dynamicznej tranzytywności ksenosa pozostaje cała rodzina terminów pokrewnych, która wykorzystuje Homerowy tekst:

- czasowniki: ksenoo: gościć, podejmować gościnnie i być podejmowanym; nawiąać stosunki przyjaźni i gościnności; przebywać na obczyźnie, iść na wygnanie; ksenidzo: przyjmować gościnnie; obdarzać podarunkami; zaskoczyć, zadziwić; być cudzoziemcem, mówić obcym akcentem; być dziwnym, osobliwym, niezwykłym;

- rzeczowniki: ksenosis: wędrówka, opuszczenie domu, podróż po obcym kraju; dziwne postępowanie, obcy sposób bycia; ksenodokos: podejmujacy, goszczacy obcych, gospodarz (zob. kseno dotes: dający gościnę - epitet Dionizosa - nie występuje u Homera); ksenia: stosunki gościnności; przyjazne stosunki; więzy gościnności; kseineion: upominek dla gościa, gościniec (dora kseineia); poczęstunek w gościnie;

- inne: ksenikos: cudzoziemski; najemny; gościnny, opiekuńczy (tu o ksenikos theos: bóstwo opiekuńcze gości); obcy, zagraniczny; ksenios: dotyczacy przyjaźni i gościnności, gościnny (tu Dzeus Ksenios: opiekun gości); obcy, cudzoziemski (kseinia: dary przyjacielskie, upominki; uczta). 
W stosunku do „niegościnnego” cyklopa tekst Homerowy wynajduje szczególny epitet: ksenodaites: pożeracz gości, cudzoziemców.

Obcy... Obie podstawowe tranzytywne dwuznaczności przypisane sa na trwałe Odyseuszowi i właściwym mu - przechodnim - sposobom bywania.

Zwróćmy od razu uwage na pewną semantyczna osobliwość. Kiedy Atena w przebraniu pastuszka wita na Itace zdezorientowanego Odyseusza, posługuje się formularnym zwrotem:

Nepios eis, o ksein', e telothen eilelouthas (XIII 236)

Niemądry jesteś, cudzoziemcze, albo przybywasz z daleka (JP, 191)

Lub niemądryś, lub bardzo przychodzisz $z$ daleka (LS, 202).

Dokładnie tego samego zwrotu używa cyklop na powitanie Odyseusza (IX 273):

Głupiś alboś z daleka przyszedł (LS, 136).

Tyś głupek jaki - o gościu - albo z daleka przybywasz (JW, 166).

Zważmy, że formularna charakterystyka ksenosa-gościa/obcego - ma postać alternatywy: głupi (jak dziecko!) albo $z$ daleka (przybywający). Ksenos byłby głupcem, gdyby był „stąd”, jeśli zaś jego dezorientacja - co do miejsca pobytu lub, w drugim przypadku, co do lokalnych zwyczajów - wynika $z$ tego, że przybywa $z$ daleka, głupcem nie jest.

Homerycka epoka nie zna jeszcze tak znajomej nam identyfikacji obcości i głupoty, co podkreśla Adorno:

„W późniejszych czasach nie rozróżniano już tak skrupulatnie między głupcami a cudzoziemcami, a nieznajomość miejscowego obyczaju, podobnie jak wszelką obcość uznawano $z$ góry za głupotę" (TWA, 82).

Nawet ignorancki potwór (jędzon, niestwora) posługuje się alternatywa, która wyklucza $z$ charakterystyki ksenosa aprioryczna koniunkcję „obcego” i „głupiego” (tudzież implikację: „obcego”, a więc 
"głupiego"), co w przyszłości stanie się kanonicznym stereotypem. Formularny zwrot użyty przez Polifema nie przeszkadza mu oczywiście w skrajnie niegościnnym podjęciu obcego. Obcy przybysz z dalekich stron - dziwny, inny, zachowujacy się, wyglądający, mówiący osobliwie (inaczej niż tutejsi) - nie zasługuje na dyskwalifikację z powodu przypisywanej mu jednoznacznie "głupoty”.

Obcy: skąd? W przytoczonej alternatywnej charakterystyce $k s e-$ nosa pojawia się słowo telothen (w innych miejscach także telothe, telothi): $\mathrm{z}$ daleka, $\mathrm{z}$ dala.

To wyraźna sugestia odpowiedzi na pytanie, skąd przybywa ksenos. Żądny pomsty Posejdon „wodzi błędnego $z$ dala od ziemi ojczystej" (I 88; JW, 35), jak mówi Zeus do Ateny. Telemach podejrzewa, że niepogrzebane kości ojca gnija gdzieś „w obcej krainie” (I 180; JW, 37), choć wkrótce, przekonany przez Atenę, powie, że ojciec żyje allothi: na obczyźnie, gdzie indziej, w innym kraju (II 131; zob. JP, 21). Atena zaś jako "gość domowy” (eidomene kseino; I 105; LS, 10) przybywa na Itake „z daleczyzny”, wedle wyrażenia jednego $z$ tłumaczy (I 428; JW, 43).

Obcy: jak? Odyseusz jako ksenos przedstawia się światu w wielu postaciach obcego/cudzoziemca.

Atena wita go przed pałacem Alkinoosa jako kseine pater (VII 28, 48; zob. XVII 553): „dziadku wędrowny” (LS, 100), „ojcze wędrowny” (JW, 130). Słowo kseinos tłumaczone bywa na różne sposoby przywołujące na myśl etruski przydomek Odyseusza (nanos): „przychodzień i tułacz, człek przychodni” (LS, 328), „włóczęga” (LS, 333).

Eumajos zwraca się do Odyseusza: daimonie kseinon (XIV 443): „dziwny gościu” (JP, 210).

Zdradna służąca Melanto ubliża Odyseuszowi: kseine talan (XVIII 327, XIX 66): nędzniku (bezczelny, zuchwały), „przybłędo” (LS, 284). 
Kiedy słowo kseinos pada w stosunku do Odyseusza ze strony zalotników, to ma ono przeważnie znaczenie pejoratywne, poniżające, a nawet jawnie obelżywe, co w przekładach oddawane jest jako: przychodzień, tułacz, włóczęga, przybłęda.

Spoza maski ksenosa wyłaniaja się rozmaite znaczenia, które, zwykle ukryte, nabieraja blasku zależnie od okoliczności.

W przestrzeni gościnności ksenos - obcy/gość - traktowany jest w myśl starych praw życzliwie i przyjaźnie.

I na odwrót, w sytuacjach antygościnnych (wyjętych spod prawa gościnności) ten sam ksenos spotyka się $z$ wrogościa, nienawiścia, które - w skrajnych przypadkach - groża mu śmiercia.

Jak gdyby ksenos był swoistym kamieniem probierczym stanów (nie)gościnności świata. Niby wyzwaniem i próbą dla świata, by okazał on swoją właściwa postać. Wędrownym kryterium gościnności, sc. niegościnności świata.

Obcy: gdzie? Szczególnym rodzajem próby sa te sytuacje, kiedy Odyseusz pojawia się $\mathrm{w}$ świecie w przebraniu nędzarza, żebraka. Gdy wraz z Eumajosem udaje się do swego pałacu, a ich widok kwituje niewierny koźlarz Melantios: kakos kakon... (XVII 217):

„Łajdak prowadzi łajdaka” (JW, 298; „Nicpoń wiedzie nicponia” [LS, 262]) - i dodaje: ptochon anieron („uprzykrzony żebrak” [JP, 249]) oraz daiton apolymantera (XVII 220; „biesiad psowacz” [tamże]; „niszczyciel uczt” [MW, 189]).

Intrygujacy jest ten epizod, gdy Odyseusz jako kakos i ptochos potyka się $z$ innym żebrakiem, o przezwisku Iros, który niespodziewanie pojawia się $\mathrm{w}$ pałacu i, podjudzany przez zalotników, lży Odyseusza oraz wyzywa go na pojedynek.

Odyseusz traktując go jako dziwnego natręta (daimoni: „Dziwny!”), usiłuje załagodzić zatarg: „Ten próg dla nas obu wystarczy” (XVIII 15-18; JP, 261). Ale zarazem zachowuje wyjątkowa czujność, spoglądając na intruza „spode łba”, co wedle Calasso oznacza u niego zawsze moment szczególnej koncentracji (zob. CAL, 349). Wolno wnosić, że do scysji dochodzi na progu: oudos - i ta oko- 
liczność jest tu istotna. Walka, która prowokuje Iros - zwycięska dla Odyseusza - toczy się o miejsce „na progu”. A jest to miejsce o wyjątkowym znaczeniu. Upodobane przez wszelkie istoty tranzytywne, między innymi przez włóczęgów, żebraków, dziadów proszalnych, błaznów i wszelkiej maści "głupków Bożych” (być może do tego korowodu należy również „wesołek”, „bywalec uczt”; zob. MW, 203). Miejsce przechodnie, szczególnie ważne dla Gościa.

Próg zapowiada jego przemianę: oudos, outis, Odys... Przekroczenie progu odmieni gościa w gospodarza, wyznaczy jego powrót do domu, do siebie. Przeistoczy także nędznego żebraka w potężnego mściciela.

Tym samym ujawni w nim wroga, śmiertelnego wroga dla akletoi: „nieproszonych gości”, okupujacych jego domostwo. Na progu dokona się podwójna metamorfoza: Nieproszony Gość stanie się na powrót Panem Domu, a biesiadujący zalotnicy zmienią się w zgraje nieproszonych gości, których Odyseusz wyprosi $-z$ właściwa mu przemyślna gwałtownością.

I wyrzuci za próg, przeprowadzajac strzałami $z$ łuku i ostrzem miecza „tam”: ekei. Progowa przemiana Odyseusza sprawi, że „nieproszeni goście” przekrocza próg ostateczny - próg śmierci - przenosząc się z życia do Hadesu, gdzie już jako cienie skarżyć się będą na swój los, wciąż zdumieni metamorfozą Odyseusza:

A król miał postać dziada złamanego laty:

Szedł o kiju, na grzbiecie świeciły mu łaty.

Nikt $z$ nas nie mógł Odysa poznać w tym człowieku,

Gdy się zjawił...

$\mathrm{Na}$ próg wskoczył, wysypał pęk strzał, okiem błysną

Okropnie... (XXIV 163-186; LS, 364-365)

„Wysoki próg”: megas oudos, z którego strącił wcześniej Irosa, by zająć wywalczone miejsce („wrócił na próg swój” [XVIII 114; LS, 278]), będzie pozycją, z której Odyseusz dokona ostatecznej egzekucji, samemu przechodząc straszliwą przemianę. 
Na progu: pomiędzy... Taksonomiczny geniusz Arystotelesa podpowiada mu $\mathrm{w}$ Poetyce znane zestawienie:

"Iliada" jest prosta i patetyczna [aploun kai pathetikon], "Odyseja" zaś zawikłana [...] i etyczna [peplegnemon kai ethike]" (1459 b, 14-15; 358).

Gdyby Arystoteles pomyślał ethos w jego archaicznym znaczeniu - jako „miejsce”, „siedzibę” - to mógłby uznać, że właściwym miejscem Odysei jest próg. Że nie-ludzko nie-boskie przygody Odyseusza dzieja się stale na progu: widzialnym i niewidzialnym. Zarazem na progu między widzialnym i niewidzialnym.

Odyseusz należy do tych nielicznych istot, którym dane jest niejednokrotne zbliżanie się do progu Hadesu. Zbliżanie i zatrzymywanie na progu.

Nimfa Kalipso wydarła Odyseusza - broton andra: męża śmiertelnego (V 129) - śmierci i przyrzekła nieśmiertelność oraz niekończącą się młodość:

Thesein athanaton kai ageraon emata panta (V 136).

Odyseusz wybrał życie i wypłynął na morze, wbrew przestrogom Kalipso: „Widzisz, co czyni morze? I chcesz morzu zaufać?” (zob. CAL, 367). Opuścił bezpieczna przystań na oddalonej od życia wyspie Ukrywającej.

Za namowa nieśmiertelnej Kirke udał się do krainy śmierci, gdzie pośród cieni zmarłych spotkał również Achillesa, najszczęśliwszego, jak mniemał, człowieka, który nawet w Hadesie włada umarłymi. Riposta Achillesa zrujnowała jego domysły:

Nie zachwalaj mi śmierci, prześwietny Odyssie!

Wolałbym za parobka służyć na cudzej roli,

u biednego chłopa, który ledwo się może utrzymać,

niż tu panować nad wszystkimi, co znikli ze świata. (XI 500; JP, 167)

Odyseusz po raz wtóry wybiera życie, pomny przestrogi Achillesa. Dwukrotnie - $z$ namysłem - pokonuje próg dzielący go już to od bo- 
skiej nieśmiertelności, już to od nieśmiertelnej sławy zaznawanej w Hadesie.

Co wybiera Odyseusz, dwakroć - w sytuacji progowej - stawiając na życie? Swoim zwyczajem wymyka się alternatywie. Przemyka się pomiędzy... Wybiera trans, opcję pośrednią, transgresywna wobec bosko-heroicznej alternatywy.

Wybiera życie. Czyli co? Nigdy niedokończona grę między śmiertelnością i nieśmiertelnością? Nieznośny niepokój nieodłączny od tej wielkiej gry?

Niepewność. Strategia trzymania w ryzach nieznośnego niepokoju i gruntownej, a więc podkopującej wszelki grunt, niepewności byłaby bliskim Odyseuszowi żywiołem.

Ten ostatni $z$ herosów, ten, który domyka cykl mitologicznych opowieści, jak pisze Calasso (zob. CAL, 348-349), jest nie tylko jednym $z$ najsłynniejszych $w$ dziejach efekciarzy, potrafiacym trzymać w napięciu, eskalować oczekiwanie i ekscytację: niechaj się ziści! Mechanizm owej eskalacji jest - jak pamiętamy - o tyle niezwykły, że od początku wiadomo, iż wszystko się już ziściło. Opowieść od początku dobiega swego końca. Tajemnica zostaje rozwiana u zarania, nie traci jednak nic ze swej zagadkowości.

Jako że napięcie i niepokój nie opadaja.. Odyseusz stale szachuje świat niepewnością. Doprawdy wiecie już, kim jestem? Odyseusz - to ów Ktoś? A może - ów Nikt? Skoro wiecie, to skąd ta mnogość pytań? Dlaczego wciąż pytacie?

Mgła niepewności nigdy nie opada do końca. Jeśli nawet momentalnie się rozsnuwa, by nagle stało się widno, to wiadomo, że za chwilę znów otula świat i rozmywa jego kontury. Stąd nieznośny niepokój.

Obecność Odyseusza jest eteryczna, utkana $z$ sukna nieobecności. Jak materiał tkany i wciąz niweczony przez „ręcznych robót świadomą" Penelopę. Dlatego w obecności Odyseusza zawsze tracimy pewność i nigdy nie czujemy się swojsko. Odyseja działa $z$ zaskoczenia, przygodnie, awanturniczo, intrygująco. Odyseusz jest odwetem za brak niepewności. 
Nieznośny niepokój jest stawką gry, do jakiej wciaga nas Odyseja. Jaka jest Odyseja. Niczym nielękające się parodii i paradoksu wezwanie, by spodziewać się niespodziewanego, oczekiwać nieoczekiwanego, zapraszać nieproszonego.

Jest też Odyseja wezwaniem do Itaki. Zewem powrotu. Pamiętamy: bezpowrotnego powracania. Jako że Itaka jest nieodmiennie pomiędzy za i przed. Między retencja wspomnienia i protencja tęsknoty. Przebłyskuje jako to niepochwytne jest, które skrywa się między przeszłością i przyszłością. „Jest” tylko cudzysłowem między słowami. „Okamgnieniem”, którego uchwycić i zatrzymać niepodobna.

Nostalgia za Itaka? To w pewnym elementarnym sensie niedorzeczność. Albowiem Itaka oznacza nie tyle tęsknotę za „było” i „będzie”, ile ukrywanie się w niewidocznej szczelinie między nimi. Pozwala oddzielać jedno od drugiego - tęsknić i oczekiwać

- sama nie będąc ani jednym, ani drugim. Sama nie będąc... Itaka jest takim rodzajem spełnienia, które natychmiast - w okamgnieniu - niweczy wszelkie spełnienie. Jest przeto niespełnieniem w najściślejszym sensie tego samozaprzecznego słowa.

Być może... Odyseję wolno czytać jako czysty opis świata w stadium pre-metafizycznym. Opis świata, w którym nie rozgościł się

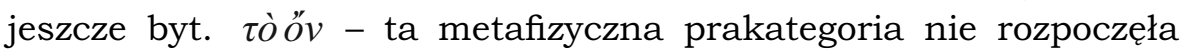
jeszcze swojej dziejowej pracy. Oto świat bycia bez bytu, który stanowi nieosiagalny horyzont metafizyki od - dajmy na to - Platona do Heideggera. Nieziszczalne marzenie wszystkich metafizyków, by doświadczyć świata, zanim różnica ontologiczna pójdzie w ruch. Przed-świat metafizyki. Jej mitologiczny przedświt.

Ziszczenie marzenia, zanim pojawiło się - i mogło się pojawić - samo marzenie.

Kto wie, czy nie na tym polega najbardziej przebiegły podstęp bogatego w fortele Odyseusza i jego Odysei.

Dygresja o gościnności bogów. Gość, jak wiemy, pojawia się na różne sposoby. I za każdym razem jest pewnym wstrząsem 
dla świata, który na mgnienie oka wstrzymuje oddech, by otwarcie przyjąc gościa. Wstrząsem dyskretnym, jak powiew Zefira, gwałtowniejszym, jak uderzenie Boreasza, albo istnym trzęsieniem ziemi, jakie wywołuje Posejdon, a potrafi je spowodować również prześladowany przezeń Odyseusz.

A jak pojawiaja się bogowie?

Podpowiada król Alkinoos, który podejmując Odyseusza, porównuje jego pojawienie się do boskiej epifanii:

A może jest to jakowyś

Bóg nieśmiertelny i ku nam z niebiosów zstapił? Bogowie

Widocznie rzecz zgoła inna przebiegle postanowili,

Boć zawsze się nam ukazuja w własnej postaci! - $Z$ wdzięczności

Za nasze sute i słynne obiaty, i hekatomby,

Schodza tu do nas i siedza, i jedza $z$ nami pospołu -

A skoro ktoś $z$ naszych ludzi, samotnie błądząc, napotka

Jednego $z$ nich na swojej drodze - nie ukrywaja sie przed nim,

Bośmy im bliscy... (VII 211-218; JW, 134)

Szczęsny czas, kiedy bogowie zjawiali się między ludźmi naocznie, nie budząc tym żadnych optycznych wątpliwości. Czas, który przywołuje młody Nietzsche, wyprawiając się w podróż do starej Grecji:

„Gdy każde drzewo może przemówić głosem nimfy, a bóg pod postacia byka porywać dziewice, gdy nagle oczom ludzi ukazuje się sama bogini Atena, jak w pięknym rydwanie wraz z Pizystratesem jedzie przez ateńskie rynki - w co wierzył każdy szanujacy się Ateńczyk - to w każdej chwili, niczym we śnie, wszystko jest możliwe, a cała natura oszałamia człowieka, jak gdyby była tylko maskarada bogów, którzy dla żartu przybierają różne postaci, by łudzić człowieka" (FN, 152-153).

Wbrew pozorom - a może właśnie dzięki nim - te dwie re(we)lacje nie sprzeczają się ze sobą. Bogowie jawią się, jak chcą. Alkinoos myli się, gdy widzi bogów jeno pod pozorem człowieka. To przypadek szczególny, jeden $z$ wielu. Nieograniczenie wielu, jako że zjawy boskie lekce sobie ważą wszelkie granice między sobą a Innym. Zaszczepiają swą inność każdej postaci, wcielają ją w każdy kształt, 
nie gardzą żadnym eidosem. Sa gościnni bezgranicznie i bezwarunkowo.

Budzą zachwyt, olśnienie, zdumienie, radość, ale także zgrozę i przerażenie. Jak choćby nimfa Kirke, która Homer przedstawia jako deine theos: dziwna, straszną, groźna boginię (X 142).

Jeśli wierzyć Calasso, to $\mathrm{w}$ świecie Homerowym bogowie pojawiają się wśród ludzi już rzadziej niż w epoce wcześniejszej. I znacznie trudniej rozpoznać ich obecność, na co Odyseusz skarży się Atenie:

Ciężko, bogini, poznać ciebie przy spotkaniu śmiertelnemu człowiekowi, choćby i bardzo był doświadczony: możesz się zjawić w każdej postaci [de gar auten panti eiskeis]. (XIII 313; JP, 193)

Świadczy to tyle o „głębokiej zażyłości z boskościa”, ile o utracie wrażliwości na kontakt $z$ bogami, którzy pojawiają się wśród śmiertelników kapryśnie, ukazując się jeno nielicznym wybrańcom i w dowolnych postaciach (zob. CAL 2, 10-11).

Troskliwa opieka Pallas Ateny nad jej ulubieńcem Odyseuszem sięga Iliady i rozpościera się nad herosem w całej Odysei, mimo jego nieufności, a nawet wyrzutów:

odtąd już ciebie nie widziałem, córko Dzeusa, ani nie zauważyłem, byś wstępowała na mój okręt i strzegła przed jakąs niedolą...

Dopiero w tłustej ziemi Feaków... (XIII 320-324; JP, 194)

Pretensja wydaje się bezpodstawna, zważywszy niewidzialna dla Odyseusza obecność Ateny u boku Telemacha i jej przelotne, skryte czuwanie nad losem herosa (interwencje u Zeusa, modły do Posejdona). Dyskretnej obecności Ateny nie wtóruja jednak gromy $z$ jasnego nieba ani Posejdonowe nawałnice i ziemiowstrzasy, co może zmylić Odyseusza, nie usprawiedliwia wszakże porzucenia ufności, iż towarzyszy mu stale „opiekuńcza obecność” bogini (zob. CAL, 237).

Ten rodzaj dyskretnej, intymnej epifanii jest szczególna, zarezerwowana dla Odyseusza - i jego syna - postacią boskiej gościnno- 
ści. Wróćmy na koniec do początku Odysei, kiedy w pieśni I Atena pokazuje się Telemachowi eidomene kseino, "podobna do gościa” (I 105; JW, 35), ściślej: przybierajacc postać/kształt/wygląd gościa. Ten eidos Atena upodobała sobie najbardziej.

Telemach wita Gościa "słowem skrzydlatym”: chaire kseine „Rozgość się cudzoziemcze, w domu moim witaj!” (I 123; LS, 11). I ofiarowuje mu gościnę bez wahania i bez żadnych warunków: „o co chcesz, się pytaj”. Na pożegnanie zaś rad wręczyć Gościowi upominek, „jakim przyjacioły wzajem się obdarzaja”: philoi kseinoi kseinoisi didousin (I 312; LS, 16).

Dopiero gdy Atena znika - „niby ptak wyfrunęła kominem” - Telemach pojmuje, że oto bogini uobecniła się w postaci Gościa:

I gdy tak stał zadumany, dreszcz grozy mu duszę owionał,

Bo odgadł tuż obok siebie wiecznego bóstwa obecność.

(I 323-324; JW, 41)

Wtenczas, sam „bogom podobny” (isotheos), „wszedł między zalotników". Odmieniony słowami Gościa, który serce wypełnił mu mocą i męstwem, ożywiając pamięć o zniknionym ojcu.

Bogowie sa gość-inni. Między ludźmi. Między Innymi. Między Gościem a Innym nie zachodzi różnica. Inność to sposób zjawiania się Gościa. Nawiedzania człowieka, który dzięki niemu odkryć się może jako ethos gościnności. Miejsce otwarte dla dajmona.

$\chi \alpha \tilde{\rho} \rho \varepsilon \xi \tilde{\xi} v \varepsilon$. 